\title{
Environmental correlates of the distribution of southern river otters Lontra provocax at different ecological scales
}

\author{
M. B. Aued, C. Chéhebar, G. Porro, D. W. Macdonald \& M. H. Cassini
}

\begin{abstract}
Endangered southern river otters Lontra provocax (huillin) are confined to southern Chile and three isolated areas of Argentina, the most important being the Nahuel Huapi National Park, where distribution surveys were conducted in 1983, 1995 and 2000. We used these survey data together with a Geographical Information System analysis to elucidate the factors that are important in determining huillin distribution at different ecological scales. There were significant heterogeneities in the distribution of huillin between river basins, between habitats, between lakes relative to dispersal routes and topography, and between sample points within a lake. From these analyses three factors emerge as potentially related to huillin distribution, and further elucidation of these are suggested as priorities for research to underpin the species' conservation. These factors are: a) the distribution of crustacean prey,
\end{abstract}

with absence of huillin from one river basin and from mountainous streams correlated with low densities of crustaceans in these places; b) human habitation, which may explain why huillin dispersed southwards, but not northwards, from the main lake, although underwater visibility may also be relevant; c) the presence of the introduced American mink Mustela vison, because although there was a positive relationship between the occurrence of mink and huillin in Lake Nahuel Huapi, there was a negative relationship in their occurrence between other lakes. We discuss possible explanations for all three factors.

Keywords American mink, Argentina, ecological scale, huillin, Lontra provocax, macro-crustacean, Mustela vison, Nahuel Huapi National Park, southern river otter.

\section{Introduction}

The southern river otter Lontra provocax (we follow Wilson \& Reeder (1993) in use of the name Lontra as opposed to the formerly used Lutra) or huillín is a threatened species confined mainly to the AndeanPatagonian region of Argentina and southern Chile (Redford \& Eisenberg, 1992; Larivière, 1999; Medina \& Chehébar, 2000), with one recent report on a river in the Patagonian steppe (Carmanchahi \& Bongiorno, 2002). Its decline was originally precipitated by hunting

M. B. Aued Departamento de Ciencias Básicas, Universidad Nacional de Luján, Rutas 5 y 7, 6700 Luján, Argentina.

C. Chéhebar Delegación Regional Patagonia, Administración de Parques Nacionales, Vicealmirante O'Connor 1188 - 8400 San Carlos de Bariloche - Río Negro, Argentina.

G. Porro Intendencia del Parque Nacional Nahuel Huapi - San Martín 24 8400 San Carlos de Bariloche, Río Negro, Argentina.

D. W. Macdonald (Corresponding author) Wildlife Conservation Research Unit, Department of Zoology, University of Oxford, South Parks Road, Oxford, OX1 3PS, UK. E-mail: david.macdonald@zoo.ox.ac.uk

M. H. Cassini Departamento de Ciencias Básicas, Universidad Nacional de Luján, Rutas 5 y 7, 6700 Luján, Argentina and Organización PROFAUNA, Corrientes $11454^{\circ}$ 47, 1043 Buenos Aires, Argentina.

Received 17 September 2002. Revision requested 11 March 2003 Accepted 6 May 2003. and, despite the fact that hunting is now prohibited, huillin are categorized as "at risk" at a national level and Endangered at an international level by IUCN (Diaz \& Ojeda, 2000; IUCN, 2002). In Argentina, huillins occur in only three isolated areas of the Andean-Patagonian region, the most important being the Nahuel Huapi National Park. Current knowledge of the species' distribution in this park is based on three surveys, undertaken in 1983, 1995 and 2000 (Chehébar, 1985; Chehébar \& Porro, 1998, in press).

In this paper our goal is to understand the factors underlying the current distribution of this Endangered species. In particular we test whether huillin distribution in the Nahuel Huapi National Park can be explained in terms of patterns in the distribution of their habitat and prey. We also explore their distribution with respect to that of a potential competitor, the introduced American mink Mustela vison. Mink were introduced in the region in the 1980s (Chehébar, 1985; Previtali et al., 1998), and their presence in the Park is of conservation concern because elsewhere this species has proven to be damaging to native prey species (Craik, 1995, 1997; Ferreras \& Macdonald, 1999; Macdonald \& Strachan 1999; Macdonald et al., 1999; Clode et al., 2000; Rushton et al., 2000; Clode \& Macdonald, 2002) and to be a potential intra-guild competitor (Macdonald et al., 2002). However, earlier fears that in the UK the American mink was inimical to 
the Eurasian otter Lutra lutra have not been upheld, rather it seems that in at least some circumstances otters are able to out-compete mink (Clode \& Macdonald, 1995; Bonesi \& Macdonald, unpub. data; Bonesi, Chanin \& Macdonald, unpub. data).

We tackled the analysis at several ecological scales: between river basins, between types of aquatic habitats (rivers, ponds and lakes), between lakes in relation to dispersal routes, between lakes in relation to topographical characteristics, and between sample points within a lake in relation to local variables. This involved a Geographic Information System (GIS) analysis based on satellite images and various thematic maps of the region, and from fieldwork, during which we conducted the first estimations of prey availability. We compared, at these different scales, the distribution of huillin with that of mink.

\section{Methods}

\section{Study area}

Nahuel Huapi National Park encompasses 710,000 ha and is located south of Neuquén Province and southwest of Rio Negro Province, Argentina (Fig. 1). The study area falls within the sub-Antarctic forest ecoregion

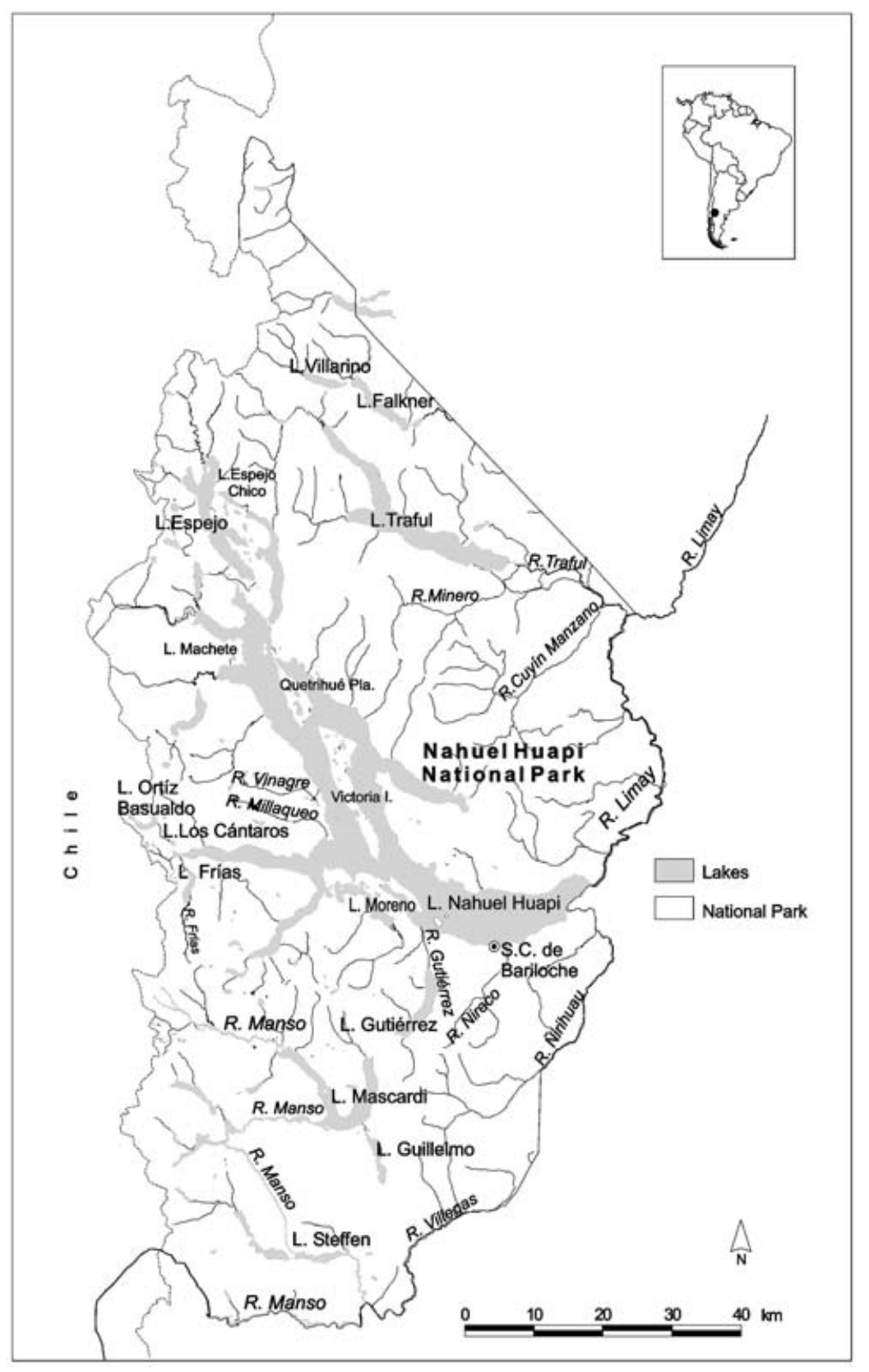

Fig. 1 Nahuel Huapi National Park (located between $40^{\circ} 8^{\prime}$ and $41^{\circ} 35^{\prime} \mathrm{S}$, and $71^{\circ} 2^{\prime}$ and $71^{\circ} 57^{\prime} \mathrm{W}$ ), showing the locations of the lakes (L.). The inset shows the position of the main figure within Argentina. 
that is characterized by mountainous forest of Nothofagus spp. and numerous lakes of glacial origin. The climate is cold-humid, with dry summers and a mean temperature of $c .10^{\circ} \mathrm{C}$. Precipitation declines along a gradient in longitude from west to east (from $3,000 \mathrm{~mm}$ to $600 \mathrm{~mm}$ ). This gradient is also evident in the vegetation, which changes from cold rain forest in the west of the Park to steppe in the east. Within the Park $10 \%$ of the land is designated as private property, mostly located along lake shores, and there are several towns; the largest, San Carlos de Bariloche, has 110,000 inhabitants. The Park encompasses two river basins with numerous streams, lakes and ponds (the latter are more eutrophic than are the lakes and have extensive littoral vegetation). The Limay River Basin flows to the Atlantic, with its source in the largest lake, Lake Nahuel Huapi, with an area of c. $526 \mathrm{~km}^{2}$. The Manso River Basin flows to the Pacific. Most water bodies are oligotrophic. The aquatic fauna is low in diversity (four exotic and five native species of fish) and productivity (Chehébar, 1985).

\section{Huillin and mink surveys}

Data on huillin and mink distribution were collected by members of the National Park Administration (Administración de Parques Nacionales, APN) (Chehébar, 1983; Porro \& Chehébar, 1995; Chehébar \& Porro, in press). The use of field signs to estimate the distribution and abundance of otters and mink has been pioneered by Strachan \& Jeffries (1995), and explored, in terms of statistical power, by Macdonald et al. (1998), and Bonesi \& Macdonald (in press) have explored, and generally validated, the reliability of such measures based on field signs. Sample sites were distributed along the water's edge of lakes, lagoons and the main rivers of the Park (only the most inaccessible were not sampled). Sites were separated by at least $3 \mathrm{~km}$. At each site $600 \mathrm{~m}$ transects were searched for signs within a $25 \mathrm{~m}$ strip along the water's edge of lakes, ponds, and rivers (following Chehébar, 1985). We used the results of three surveys conducted from December 1982-April 1983 (100 sites visited), during February-May 1995 (216 sites) and during April-October 2000 (208 sites). Site locations were selected afresh at random for each survey and thus the distribution of the sampling sites was not the same between surveys. The huillin and mink survey databases were incorporated into a GIS (the 'map of signs') by APN.

\section{GIS analyses}

For each transect searched for otter signs the following local variables were recorded: (1) presence or absence of roads in a buffer zone of $300 \mathrm{~m}$ radius around the midpoint of each transect; (2) presence or absence of tributaries in the same buffer zones; (3) slope, in intervals of $0-5,6-14,15-21,22-27,28-32,33-37,38-42^{\circ}$; (4) human settlements, as pristine (protected lands without human settlements and with the original vegetation cover), and low (human settlements with abundant native vegetation cover), medium (human settlements with poor native vegetation cover) and high degradation (cities and towns); (5) precipitation (considering the highest value of the two nearest isohyets to each transect), as $<1,000,1,000-1,400,1,400-2,000,2,000-3,000$, $>3,000 \mathrm{~mm}$; (6) vegetation 'complexity', as complex forest (closed forest always green with shrub substrate) simple forest (open forest with or without shrub substrate) and unforested (urban and steppe areas). These categories were created by grouping the land cover categories recorded in the APN land cover map. Candidate geographic variables that could be associated with otter distribution were read from digital maps provided by APN. Maps at a scale of 1:100,000 yielded data on roads, lakes, rivers, elevation contours and private lands, and 1:500,000 maps gave information on land cover. Using the GIS software ArcView v. 3.2 (ESRI, Redlands, California) we added map layers for precipitation, slope, elevation and habitat degradation. We digitized a precipitation map from the analogue map published by APN (1986) and produced a digital elevation model using the digital elevation contours map, from which a slope map was derived. We used two satellite images in Landsat thematic mapper (band 3, 4, and 5) 232-088 and 232-089, 2000, provided by Comisión Nacional Aeroespacial. The images (at 1:100,000) were interpreted visually by colour, texture and spatial context to obtain a map of levels of habitat degradation along the lake shores, expressed in categorical terms of degree of loss of native vegetation coverage (areas that present a high visual contrast in comparison to areas with native vegetation) on the nearest $300 \mathrm{~m}$ from the coast. A map of private land holdings was used to locate human settlements. All thematic maps used the Gauss-Kruger projection.

Dispersal opportunities were quantified in terms of the minimum distance between the shore of Lake Nahuel Huapi (the potential centre of dispersal; Porro \& Chéhebar, 1995) and the other lakes. In addition, for each lake we considered: (1) area and perimeter, (2) number of tributaries, and (3) length of roads $(\mathrm{km})$ traversing a buffer fringe of $300 \mathrm{~m}$ around the lake.

\section{Crustacean surveys}

In this region huillin diet is comprised almost exclusively of macro-crustaceans of the genera Aegla and Samastacus, which are endemic to South America (Chehébar, 1985; see 
Medina (1997) for a general account of the species' diet). In rivers these freshwater crustaceans prefer moderate currents and rocky bottoms, and in lakes they abound on submerged rocky shores (Burns, 1972). We sampled these crustaceans using standard methods (Lopretto, 1995; Pádua Bueno \& Bond-Buckup, 2000). In April 2002 we sampled for crustaceans at 51 sites on the otter survey transects; sites in rivers were selected based on accessibility. In the Manso Basin we visited Lake Mascardi, Lake Steffen and the Guillelmo stream. In the Limay Basin we sampled four lakes (Nahuel Huapi, Moreno, Gutiérrez and Frias), one pond (Cantaros), four western streams and rivers (Frias, Millaqueo, Vinagre and Cantaros), three central streams (Gutierrez, Nireco and Cuyin Manzano), and two eastern rivers (Traful and Limay). The locations of rivers and streams were associated with characteristics of relief, precipitation and vegetation: (1) the western rivers and streams flow between mountains above $1,800 \mathrm{~m}$ with forest vegetation and annual precipitation of 2,000-3,000 $\mathrm{mm},(2)$ the eastern rivers flow into wide valleys between mountains reaching no more than $1,300 \mathrm{~m}$, with steppe vegetation and annual precipitation $<1,000 \mathrm{~mm}$, and (3) the central streams are intermediate.

At each of the 51 sample sites we stratified sampling based on five categories of particle size that formed $>50 \%$ of the substrate: large rocks $(>30 \mathrm{~cm})$, small rocks $(20-30 \mathrm{~cm})$, stones $(5-20 \mathrm{~cm})$, gravel $(<5 \mathrm{~cm})$ and mud (invariably with rush vegetation). At each stratum found at each site, five $1 * 1 \mathrm{~m}$ quadrats were sampled, each separated by $10 \mathrm{~m}$. The distance from the shore varied between 1-4 m, because we searched for crustaceans up to a water depth of $0.5 \mathrm{~m}$. Each quadrat was sampled by hand, sifting the substrate as we searched for crustaceans (Pádua Bueno \& Bond-Buckup, 2000). Where the current was strong, we located a survey net ahead of the current to collect any dislodged crustaceans. Crustacean type and number were counted in each quadrat and net sample. Samples taken within $500 \mathrm{~m}$ of outlets of rivers and streams were allocated to the data for the associated lake or pond. In Lake Frías water visibility was measured with a $32 \mathrm{~cm}$ diameter Secchi disk.

\section{Statistical analyses}

In our analysis of factors affecting the distribution of huillin between lakes we estimated the proportion of transects with signs (positive transects/total transects) for lakes at which otters and mink were present on the 1995 and 2000 surveys of the Limay Basin. We excluded the 1983 survey because otters were then found almost exclusively at Lake Nahuel Huapi and because mink were absent from the Limay Basin. The between-lake analysis considered four variables: area, the length of the perimeter of the lake divided by the number of (a) tributaries and (b) roads traversing a buffer fringe of $300 \mathrm{~m}$ around the lake, and proportion of transects with mink signs. We used a Principal Component Analysis (PCA) to summarize these variables. Variables with component loadings greater than 0.7 were considered to contribute high scores to the component. We then conducted a linear regression analysis to determine the effect of environmental variables on huillin and mink distribution at the between-lake level (Manly et al., 1993). We used the first three factors of the PCA analysis as independent variables and the presence or absence of otter as a binary dependent variable.

We then undertook an analysis of factors affecting the distribution of mink within lakes, using the 2000 data set for otters and mink, and considering six local variables: human settlements, coastal vegetation complexity, presence of roads, presence of tributaries, slope, and precipitation. The two analyses were similar but differed in that the between-lake analysis used a linear regression whereas the within-lake analysis used a stepwise regression (because the former involved a measured variable whereas the latter involved a $0 / 1$ dichotomy). A further difference between these analyses is that for the within-lake comparison we used a Quartimax rotation to separate the effects of parameters known to co-vary.

\section{Results}

\section{Between river basins}

In the Limay Basin $44.9 \%$ of transects revealed signs of huillin but they were absent from the Manso Basin in all three surveys (Table 1). Mink were present at similar prevalence in both basins $\left(\chi^{2}=0.57, \mathrm{df}=1, \mathrm{P}=0.45\right)$.

\section{Between types of aquatic habitats (rivers, ponds and lakes)}

Within the Limay River Basin, there was a significant difference in otter distribution between types of habitats (Table $1, \chi^{2}=233.86, \mathrm{df}=2, \mathrm{P}<0.00001$ ). There were no signs of otters in rivers and ponds, with the exceptions of two riverine sites less than $500 \mathrm{~m}$ from Lake Nahuel Huapi. We excluded six samples that were collected from ponds on Victoria Island and Quetrihué Peninsula because the presence of otters in these ponds might be due to their situation within the larger water body, thereby confounding interpretation. In contrast, there were no significant differences between aquatic habitats for the presence of mink (Table $1, \chi^{2}=4.38, \mathrm{df}=2$, $\mathrm{P}=0.11$ ). 
Table 1 Occurrence of signs of huillin and mink (data aggregated from the three surveys of 1983, 1995 and 2000, see text for details) by river basin, habitat and potential routes of dispersal (for the latter, see text for details).

\begin{tabular}{llccc}
\hline & Locality & Total number of samples & Positive for huillin (\%) & Positive for mink (\%) \\
\hline River basin & Limay & 401 & $180(44.9)$ & $176(43.9)$ \\
\multirow{2}{*}{ Habitat } & Manso & 104 & $0(0)$ & $39(37.5)$ \\
& Rivers & 35 & $1(2.9)$ & $18(51.4)$ \\
\multirow{2}{*}{ Direction of dispersal } & Ponds & 11 & $1(9.1)$ & $2(18.2)$ \\
& Lakes & 355 & $178(50.1)$ & $156(43.9)$ \\
& South & 21 & $36(50.0)$ & $4(19.0)$ \\
\hline
\end{tabular}

\section{Between lakes in relation to dispersal routes}

In 1983, huillin signs were found mainly in Lake Nahuel Huapi and nearby lakes. Due to the geographical distribution of water bodies in the region, there were two plausible routes for dispersal, to the south or to the north (Fig. 1). In the surveys conducted in 1995 and 2000 there were no signs of huillin in the lakes to the south, even those that were within $5 \mathrm{~km}$ of Lake Nahuel Huapi (Table 2). In contrast, signs of otters were found in $50 \%$ of transects to the north. Over the succession of surveys, huillin appeared to spread to the north of Lake Nahuel Huapi (Table 2). In 1983, there were no signs of otters in Lakes Traful, Villarino and Falkner. In 1995 Lake Traful was occupied, and in 2000 the farthest lakes also revealed signs of huillin.

\section{Between lakes in relation to topography and mink}

The first and second factors of the PCA applied to area, perimeter/number of tributaries, perimeter/number of roads, and proportion of mink signs explained 45.5 and $32.3 \%$ of the variation in the data, respectively. Factor 1 had high positive values for area and tributaries, and Factor 2 had high positive values for roads and very high $(-0.94)$ for mink. The linear regressions between otter distribution and the PCA factors were significant (positively) only for Factor $2\left(r^{2}=0.89, \mathrm{P}<0.00002\right)$. Simple correlations between otter distribution and proportion of roads $(r=0.22, \mathrm{P}>0.05)$ and proportion of mink signs $(r=-0.62, \mathrm{P}<0.05)$ revealed that mink

Table 2 Proportion of transects with signs of huillin in the surveys of 1983, 1995 and 2000 (see text for details), and the distance (in $\mathrm{km}$ ) of the lakes from Lake Nahuel Huapi, the centre of dispersal (Fig. 1).

\begin{tabular}{lllll}
\hline Lake & 1983 & 1995 & 2000 & $\mathrm{~km}$ \\
\hline Traful & 0 & 0.9 & 0.9 & 17.24 \\
Villarino & 0 & 0 & 1 & 29.32 \\
Falkner & 0 & 0 & 0.5 & 29.74 \\
\hline
\end{tabular}

presence was responsible for the effect of Factor 2, and suggested a strong negative spatial relationship between these species between lakes (Fig. 2).

\section{Between sample points within a lake}

Lake Nahuel Huapi was substantially larger than the other lakes and we therefore conducted two separate within-lake analyses, one for this lake and a second analysis for the other six lakes (Correntoso, Espejo, Faulkner, Perito Moreno, Traful and Villarino). These analyses used data only from the 2000 survey and hence avoided any confounding effect that would arise if the otters' habitat preferences changed over the period of the three surveys. For Lake Nahuel Huapi the first, second and third factors of the PCA applied to human settlements, coastal vegetation complexity, presence of roads, presence of tributaries, slope, and precipitation explained $32.0,21.7$ and $17.1 \%$ of the variation in the data, respectively. Factor 1 had high positive values for precipitation and coastal vegetation complexity and high

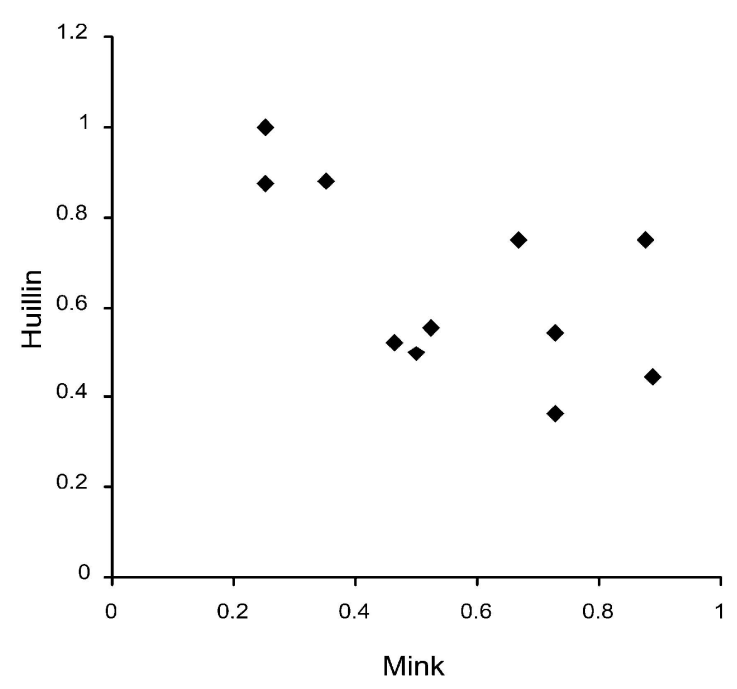

Fig. 2 Relationship between the distribution of mink and huillin. Each point corresponds to the probability of finding signs in a lake during the 1995 or 2000 survey. 
negative values for human presence. Factor 2 had high positive values for slope and tributaries, and Factor 3 for roads. The logistic regressions between otter distribution and the PCA factors were significant (positively) only for Factor $1\left(\chi^{2}=33.87, \mathrm{P}<0.0001\right)$ and the same trend was found for mink $\left(\chi^{2}=13.14, \mathrm{P}<0.003\right)$. Due to the inclusion of both local habitat features and human settlement within this one factor, the analysis does not allow us to disentangle these two effects. However, within Lake Nahuel Huapi there was a significant positive association between transects with signs of huillin and those with signs of mink (Spearman correlation, $\mathrm{n}=158$, $\left.r_{\mathrm{s}}=0.32, t=4.24, \mathrm{P}<0.001\right)$.

For the rest of the lakes, the first, second and third factors of the PCA explain 30.7, 30.0 and $18.2 \%$ of the variation in the data, respectively. Factor 1 had high negative values for coastal vegetation complexity. Factor 2 had high negative values for human settlements and Factor 3 for slope. The logistic regressions between otter distribution and the PCA factors were significant (positively) only for Factor $2\left(\chi^{2}=3.72, \mathrm{P}<0.053\right)$. This analysis, therefore, does allow us to isolate human settlements from other local environmental factors and to identify it as correlating negatively with otter distribution. In contrast, the logistic regressions between mink distribution and the PCA factors were significant (positively) only for Factor 1, coastal vegetation complexity $\left(\chi^{2}=11.91, \mathrm{P}<0.0006\right)$. Consequently, the positive association between the distributions of huillin and mink that was statistically significant in Lake Nahuel Huapi was not apparent within the other lakes (Spearman correlation, $\left.\mathrm{n}=57, r_{\mathrm{s}}=0.12, t=0.89, \mathrm{P}=0.38\right)$.

\section{Prey distribution}

We found no crustaceans in the Manso Basin or in the mountainous rivers (Table 3 ). In contrast, we found crustaceans in the lakes of the Limay Basin, including

Table 3 Number of samples (quadrats) and samples containing crustaceans, by river basin, habitat and potential routes of huillin dispersal (for the latter, see text for details).

\begin{tabular}{llcc}
\hline & & & No. of \\
Variables & Locality & $\begin{array}{l}\text { No. of } \\
\text { samples } \\
\text { samples with } \\
\text { crustaceans }\end{array}$ \\
\hline River basin & Manso & 45 & 0 \\
Habitat & Limay & 263 & 71 \\
& Western rivers & 21 & 0 \\
& Central rivers & 25 & 2 \\
& Eastern rivers & 34 & 15 \\
& Ponds & 10 & 0 \\
Direction of dispersal & Lakes & 168 & 53 \\
& South & 40 & 19 \\
& Centre & 128 & 34 \\
\hline
\end{tabular}

the two lakes located to the south of Lake Nahuel Huapi where there was no evidence of the presence of otters, and in the steppe rivers, which also appeared to be devoid of otters. There were significant differences in the density of crustaceans between different aquatic substrates (Kruskal-Wallis test, $H_{4}=12.9, \mathrm{P}=0.01, \mathrm{n}=40$ ). Small rocks supported the highest densities (mean $=2.7$ crustaceans per $\mathrm{m}^{2}$ ), big rocks supported intermediate densities (1.5), and stones (0.6), small rocks (0.0) and mud (0.4) supported low crustacean densities.

\section{Discussion}

There were significant heterogeneities in the distribution of southern river otters at different ecological scales: between river basins; between types of aquatic habitats (rivers, ponds and lakes), between lakes in relation to dispersal routes, between lakes in relation to topographical characteristics, and between sample points within a lake in relation to local variables. Several ecological factors may plausibly influence these patterns of distribution, including availability of food, shore-line habitat quality (which determines the quality and availability of den sites), barriers to dispersal, competition with mink, competition with exotic salmonids, human settlements, human activities and physical structure of water bodies. Our analyses enable us to evaluate the likely impact of some of these on huillin distribution at the ecological scales examined and highlight important questions to be tackled in the future.

\section{Between river basins}

There was no evidence of otters in the Manso River Basin between 1983-2000. Porro \& Chéhebar (1995) found suitable habitat for huillin along the shorelines of lakes in the Manso Basin and so concluded that the species' absence was attributable to low density of food, considering that macro-crustaceans comprised $99 \%$ of huillin diet in this region (Chehébar, 1985). Our findings support this conclusion (Table 3), revealing a low density, or even absence, of crustaceans, perhaps due to physical (e.g. water temperature) or ecological characteristics of the lakes. As suggested elsewhere (Chehébar et al., 1984), another possible explanation for the absence of macrocrustaceans and/or of discontinuities in their distributions, especially in the Manso Basin, could lie in the area's glaciation history. The full glaciation could have wiped out macro-crustaceans from all or part of the basin and their recolonization could have been prevented by barriers such as large waterfalls. 


\section{Between types of aquatic habitats (rivers, ponds and lakes)}

At a large scale, Chéhebar \& Porro (1998) suggested that the absence or scarcity of huillin from rivers and streams in the mountainous regions of the Park was due to low food abundance. Again, our analyses support their conclusion, insofar as we found no crustaceans in the mountainous watercourses, while they were abundant in the steppe rivers and streams (Table 3).

\section{Between lakes in relation to dispersal routes}

In 1983 there was evidence of huillin presence only in Lake Nahuel Huapi and nearby lakes. In 1995 and 2000 signs of otters were found in lakes located $30 \mathrm{~km}$ to the north but not to the south, despite the fact that two unoccupied southern lakes, Gutiérrrez and Frías, were closer to Lake Nahuel Huapi than were any of the lakes occupied to the north, and we found crustaceans in both of these southern lakes. The absence of emigration to the south remains unexplained but one possibility is that human settlements on the Gutierrez River represent a barrier to otter (but not mink) dispersal (Chéhebar \& Porro, 1998). Lake Frías may be unsuitable for otters because of low visibility in the murky water. We estimated visibility with a Secchi disk $(1.1 \mathrm{~m})$ and found that it was significantly lower than in other lakes $(14.4 \mathrm{~m}$ for Lake Nahuel Huapi and $17.0 \mathrm{~m}$ for Lake Gutiérrez; Pedrozo et al., 1993, 1997). This poor visibility is due to abundant suspended sediment carried in by the Upper Frías River tributary. Human barriers to dispersal and low visibility are possible explanations of the absence of otters south of Lake Nahuel Huapi. To understand this pattern, which is important to conservation, it will be a priority to monitor dispersal attempts of individual otters living in Lake Nahuel Huapi near the rivers that connect to the southern lakes such as Gutierrez and Frías.

\section{Between lakes in relation to topography}

Comparisons between the topographical characteristics of different lakes did not reveal strong associations with the probability of finding huillin, but most lakes that were smaller than $4 \mathrm{~km}^{2}$ revealed no signs of otters. As mentioned above, otters were absent from most lagoons and rivers. Perhaps these smaller bodies of water are insufficient to sustain huillin territories. The only two such smaller waterbodies at which signs of otters were found (Machete Lagoon and Lake Espejo Chico) were very close to, and connected with, large lakes.

\section{Between sample points within a lake}

At a local scale we conducted two analyses, one for Lake Nahuel Huapi and another for the rest of the lakes that had evidence of otters. Huillin were less frequently found on narrow shorelines with simple vegetation than on other shorelines within Nahuel Huapi (see also Chéhebar, 1985). We also found a negative correlation with human presence, which did not affect mink. In Lake Nahuel Huapi interpretation was confounded because most variables, including huillin distribution, were correlated with the gradient in longitude. At the other lakes, otters were not affected by this gradient, although mink were, and slope and vegetation showed little variation. In the latter case, it was therefore possible to identify the effect of human perturbation as the main factor explaining the distribution of this Endangered species.

Our analyses reveal a possible paradox as there was a positive association between the presence of huillin and mink within Lake Nahuel Huapi but a negative association in their occurrence between the other lakes. There is evidence of overlap in feeding niche between these two species (Chehébar et al., 1984; Chehébar, 1985; Previtali et al., 1998) and thus the possibility of competition between them. Invasive species, in this case the mink, can threaten local competitors through intra-guild aggression (Macdonald \& Thom, 2001) but in this case there is observational and experimental evidence that native otters can oust invasive mink (Clode et al., 2000; Bonesi \& Macdonald, unpub. data; Bonesi, Chanin \& Macdonald, unpub. data). Therefore a possible interpretation of the apparent paradox could be as follows. At the wider scale, between lakes and ponds, intra-guild competition between native otters and introduced mink has caused mink to be rare where otters are abundant. On the finer scale, within Lake Nahuel Huapi the shared habitat preferences and diets of the two species leads to a broad association between their distributions, both congregating in those habitats that suit them within this vast and heterogeneous lake. This hypothesis is partially support by three lines of evidence. Firstly, in our analysis, the presence of both species correlated positively with the gradient in longitude that was represented statistically by the first component of the PCA, indicating that both were affected by similar environmental factors. Secondly, it is generally the case that there is overlap in diet between otters and mink (reviews in Macdonald \& Strachan, 1999). Thirdly, Bonesi, Chanin \& Macdonald, (unpub. data) found evidence in lowland UK not only that mink disappeared from waterbodies that had been recolonized by otters but also that mink were most likely to persist in the presence of otters in places where suitable terrestrial habitat was available within a few 
hundred metres of the water. We therefore speculate that huillin and mink are both attracted to zones of suitable habitat, within which the superior competitor will monopolize the best patches but around which the expansive Lake Nahuel Huapi provides sufficient refuges for the weaker competitor to persist, perhaps with some niche-shift. Elsewhere, where the diversity of prey and/or habitat does not permit the mink to co-exist with the larger otter, mink will be ousted by otters, except on those lakes too small to sustain otter territories, in which cases mink may prosper. More detailed research will be necessary to untangle the factors affecting mink distribution but while this may have important implications for other native species in the region the likelihood is that mink are the inferior competitor in any competition with huillin.

In conclusion, our analyses reveal three factors as potentially related to huillin distribution: a) the distribution of crustacean prey, as absence of huillin from one river basin and from mountainous streams was correlated with low densities of crustaceans in these places; b) human habitation, which constrained huillin distribution at a local level and may explain why huillin dispersed southwards, but not northwards, from the main lake (underwater visibility may also be relevant); c) the presence of mink, as while there was a positive relationship between the occurrence of mink and huillin in Lake Nahuel Huapi, there was a negative relationship in their occurrence between other lakes. We suggest that further elucidation of these factors are priorities for research to underpin the species' conservation.

\section{Acknowledgements}

We are grateful for the sponsorship of St Louis Zoo (and especially the enthusiasm of Dr Cheryl Asa) and the PTES. Silvia Ortubay, Gustavo Iglesias, Anahí Pérez, Pablo Martínez and other members of the Delegación Regional Patagonia (Administración de Parques Nacionales) collaborated in different aspects of the computational work. Raul González, and other members of the Cuerpo de Guardaparques del Parque Nacional Nahuel Huapi collaborated with the logistics of the field work. Daniel Somma and other members of the Central Office of Administracion de Parques Nacionales provided access to computers and work programmes, Dr. Amalia Denegri, Patricio Machi and other members of the Grupo ded Evaluación y Manejo de Recursos Icticos (CRUB) collaborated in the design of field work, Dr Estela Lopretto, Miguel Shuldt and Alejandra Rumi provided information on macro-crustaceans. Laura Bonesi made helpful comments on an earlier draft. International Otter Survival Fund supported the 2000 survey. MHC is supported by the Consejo Nacional de Investigaciones Científicas y Técnicas. The Agencia Nacional de Promoción Científica y Técnica and the Universidad Nacional de Lujan provided part of the funds for this research.

\section{References}

Administración de Parques Nacionales (APN) (1986). Plan de Manejo, Parque Nacional Nahuel Huapi. Administración de Parques Nacionales, Buenos Aries, Argentina.

Bonesi, L. \& Macdonald, D.W. (in press) Evaluation of sign survey as a way to estimate the relative abundance of mink. Journal of Zoology.

Burns, W. (1972) South American freshwater crabs. Transactions of the American Fisheries Society, 4, 595-607.

Carmanchahi, P. \& Bongiorno, M. (2002) ¡Viven! Huillines en el Limay. Vida Silvestre, 80, 36-37.

Chehébar, C. (1983) Relevamiento del huillin, Lutra provocax, en el Parque Nacional Nahuel Huapi. Administración de Parques Nacionales, Buenos Aries, Argentina.

Chehébar, C. (1985) A survey of the southern river otter Lutra provocax Thomas in Nahuel Huapi National Park, Argentina. Biological Conservation, 32, 299-307.

Chehébar, C. \& Porro, G. (1998) Distribución y estatus del huillín (Lutra provocax) en el Parque Nacional Nahuel Huapi, Argentina. Vida Silvestre Neotropical, 7, 99-106.

Chehébar, C. \& Porro, G. (in press) Monitoreo de la distribución del huillín, Lontra provocax en el Parque Nacional Nahuel Huapi - Año 2000. Technical Report of the Argentine Administration of National Parks, Bariloche, Argentina.

Chehébar, C., Gallur, A., Giannico, G., Gottelli, M. \& Yorio, P. (1984) Relevamiento del Huillin, Lutra provocax, en los Parques Nacionales Lanín, Puelo y Los Alerces, y evaluación de su estado de conservación en Argentina. Administración de Parques Nacionales, Buenos Aires, Argentina.

Clode, D. \& Macdonald, D.W. (1995) Evidence for food competition between mink (Mustela vison) and otter (Lutra lutra) on Scottish islands. Journal of Zoology (London), 237, 435-444.

Clode, D. \& Macdonald, D.W. (2002) Invasive predators and the conservation of island birds: the case of the American mink Mustela nivalis and terns Sterna spp. in the Western Isles, Scotland. Bird Study, 49, 118-123.

Clode, D., Birks, J.D.S. \& Macdonald, D.W. (2000) The influence of risk and vulnerability on predator mobbing by terns (Sterna spp.) and gulls (Larus spp.). Journal of Zoology (London), 252, 53-59.

Craik, J.C.A. (1995) Effects of North American mink on the breeding success of terns and smaller gulls in west Scotland. Seabird, 17, 3-11.

Craik, J.C.A. (1997) Long-term effects of North American mink Mustela vison on seabirds in western Scotland. Bird Study, 44, 303-309.

Diaz, G.B. \& Ojeda, R.A., eds (2000) Libro rojo de mamíferos amenazados de la Argentina. Technical Report of the Sociedad Argentina para el Estudio de los Mamíferos, Argentina. 
Ferreras, P. \& Macdonald, D.W. (1999) The impact of American mink Mustela vison on water birds in the Upper Thames. Journal of Applied Ecology, 36, 701-708.

IUCN (2002) 2002 IUCN Red List of Threatened Species. IUCN, Gland, Switzerland [http:/ /www.redlist.org, accessed 29 May 2003]

Larivière, S. (1999) Lontra provocax. Mammalian Species, 610, 1-4.

Lopretto, E. (1995) Crustacea malacostraca: Ecosistemas de Aguas Continentales, Metodología para su estudio. Editorial Sur, 1001-1037.

Macdonald, D.W., Mace, G. \& Rushton, R. (1998) Proposals for Future Monitoring of British Mammals. Report published by Department of the Environment, Transport and the Regions, London, UK.

Macdonald, D.W. \& Strachan, R. (1999) The Mink and the Water Vole: Analyses for Conservation. Wildlife Conservation Research Unit and Environment Agency, Oxford, UK.

Macdonald, D.W. \& Thom M.D. (2001) Alien carnivores: unwelcome experiments in ecological theory. In Carnivore Conservation (eds J.L. Gittleman, S.M. Funk, D.W. Macdonald \& R.K. Wayne), pp. 93-122. Cambridge University Press, Cambridge, UK.

Macdonald, D.W., Barreto, G.R., Ferreras, P., Kirk, B., Rushton, S., Yamaguchi, N. \& Strachan, R. (1999) The impact of American mink, Mustela vison, as predators of native species in Britain. In Advances in Vertebrate Pest Management (eds J. Pelz, D. Cowan \& C. Freare), pp. 5-24. Filander Verlag, Fürth, Germany.

Macdonald, D.W., Sidorovich, V.E., Maran, T. \& Kruuk, H. (2002) The Darwin Initiative. European Mink, Mustela lutreola: Analyses for Conservation. Wildlife Conservation Research Unit, Oxford, UK.

Maxwell, S.E. \& Delaney, H.D. (1990) Designing Experiments and Analyzing Data. Wardsworth, Belmont, USA.

Manly, B.F., McDonald, L.L. \& Thomas D.L. (1993) Resource Selection by Animals: Statistical Design and Analysis for Field Studies. Chapman \& Hall, London, UK.

McGarigal, K., Cushman, S. \& Stafford, S., (2000) Multivariate Statistics for Wildlife and Ecology Research. Springer-Verlag, New York, USA.

Medina, G. (1997) A comparison of the diet and distribution of southern river otter (Lutra provocax) and mink (Mustela vison) in Southern Chile. Journal of Zoology (London), 242, 291-297.

Medina, G. \& Chehébar, C. (2000) Propuesta de estudio y análisis de antecedentes para la selección de áreas prioritarias para la conservación de poblaciones de huillin (Lontra provocax Thomas) en la ecoregión Selva Valdiviana. Informe a Proyecto APNINTA-FVSA-CODEFF, Universidad Austral de Chile, WWF/USA - Agreement \#FC2, Valdivia, Chile.

Pádua Bueno, A.A. \& Bond-Buckup, G. (2000) Dinamica populacional de Aegla platensis Schmitt. Revista brasileira de Zoologia, 17, 43-49.

Pedrozo, F., Chillrud, S., Temporetti, P. \& Diaz, M. (1993) Chemical composition of rivers and lakes of northern
Patagonian Andes ( $\left.35.5^{\circ}-42^{\circ} \mathrm{S} ; 7-11^{\circ} \mathrm{W}\right)$ (Rep. Argentina). Verlagh International Vereine Limnologie, 25, 207-214.

Pedrozo, F., Alcade, R. \& Manuel, M. (1997) Estado Trofico del Lago NAHUEL HUAPI y Estimación Preliminar de su Posible Evolucion. Technical Report of Administración de Parques Nacionales, Buenos Aries, Argentina.

Porro, G. \& Chehébar, C. (1995) Monitoreo de la distribución de huillin (Lutra provocax) en el Parque Nacional Nahuel Huapi, Argentina. Delegación Técnica Regional Patagonia, Administración de Parques Nacionales, Buenos Aries, Argentina.

Previtali, A., Cassini, M.H. \& Macdonald, D.W. (1998) Habitat use and diet of the American mink (Mustela vison) in Argentinian Patagonia. Journal of Zoology (London), 246, 482-486.

Redford, K.H. \& Eisenberg, J.F. (1992) Mammals of the Neotropics. Volume 2 The Southern Cone. The University of Chicago Press, Chicago, USA.

Rushton, S.P., Barreto, G.W., Cormack, R.M., Macdonald, D.W. \& Fuller, R. (2000) Modelling the effects of mink and habitat fragmentation on the water vole. Journal of Applied Ecology, $37,475-490$.

Wilson, D.E. \& Reeder, D.M. (1993) Mammal Species of the World: A Taxonomic and Geographic Reference. Smithsonian Institution Press, Washington, DC, USA.

\section{Biographical sketches}

María Bettina Aued specialises in the use of GIS and processing of geographical information. She has participated in several projects on conservation of Argentinean biodiversity.

Claudio Chehébar has studied the southern river otter in the Nahuel Huapi area and is working in planning, professional assistance for national parks, and assessment of human activities in the protected areas.

Gerardo Porro has recently been working in the Resources Management Department of Nahuel Huapi National Park and is currently working as field technician for ecology projects in South Georgia.

David Macdonald specialises in research on mammals, is coordinating projects worldwide on invasive mammals, specifically on the impact of American mink, and has widespread experience of field research in South America.

Marcelo H. Cassini specialises in ecology and behaviour of mammals. He is involved in projects on conservation of endangered species, sustainable use of species with commercial value, control of invasive species and design of protected areas. 